\title{
Removing Ammonium From Contaminated Water Using Purolite C100E: Batch, Column, and Household Filter Studies
}

\section{Dai Quyet Truong}

University of Technology Sydney

\section{Paripurnanda Loganathan}

University of Technology Sydney

\section{Le Minh Tran}

Hanoi University of Science and Technology (HUST)

\section{Duc Loi Vu}

Vietnam Academy of Science and Technology

Tien Vinh Nguyen ( $\boldsymbol{\nabla}$ tien.nguyen@uts.edu.au )

University of Technology Sydney https://orcid.org/0000-0003-3893-1217

\section{Saravanamuthu Vigneswaran}

University of Technology Sydney

\section{Gayathri Naidu}

University of Technology Sydney

\section{Research Article}

Keywords: Ammonium removal, Contaminated water, lon exchange, Household water filter, Purolite C100E resin

Posted Date: August 24th, 2021

DOI: https://doi.org/10.21203/rs.3.rs-804875/v1

License: (c) (1) This work is licensed under a Creative Commons Attribution 4.0 International License. Read Full License

Version of Record: A version of this preprint was published at Environmental Science and Pollution Research on October 16th, 2021. See the published version at https://doi.org/10.1007/s11356-02116945-1. 


\section{Removing ammonium from contaminated water using Purolite C100E: Batch, column, and}

\section{2 household filter studies}

4 Dai Quyet Truong ${ }^{1,2}$, Paripurnanda Loganathan ${ }^{1}$, Le Minh $\operatorname{Tran}^{2}$, Duc Loi $\mathrm{Vu}^{3}$, Tien Vinh Nguyen ${ }^{1 *}$, 5 Saravanamuthu Vigneswaran ${ }^{1}$, Gayathri Naidu ${ }^{1}$

$6 \quad{ }^{1}$ Faculty of Engineering and IT, University of Technology Sydney (UTS), Sydney, Australia

$7{ }^{2}$ School of Environmental Science and Technology, Hanoi University of Science and Technology

8 (HUST), Hanoi, Vietnam

$9 \quad{ }^{3}$ Institute of Chemistry, Vietnam Academy of Science and Technology (VAST), Hanoi, Vietnam

10 * Corresponding author: Tien Vinh Nguyen, Email: Tien.Nguyen@uts.edu.au; Tel: 61-2-95142620; Fax:

$11 \quad 61-2-95147803$

13 ABSTRACT

14 Ammonium removal from drinking water to protect human and environmental health is one of the major global concerns. This study evaluates the performance of Purolite C100E, a commercial cation exchange resin, on eliminating ammonium in synthetic and real contaminated groundwater. The results

17 demonstrate that the $\mathrm{pH}$ operation range of the resin for better ammonium removal is 3 to 8 , while the 18 optimum contact time was about $30 \mathrm{~min}$. The kinetics of the ammonium removal process followed both 19 the Pseudo-first order and Pseudo-second order models. Equilibrium data of ammonium removal fitted 20 both the Langmuir and Freundlich isotherm models with the maximum Langmuir ion exchange capacities 21 for initial ammonium concentrations of 10-200 mg/L and 50-2000 mg/L reaching $18.37 \mathrm{mg} / \mathrm{g}$ and 40.16 $22 \mathrm{mg} / \mathrm{g}$, respectively. The presence of co-ions in the water reduced the ammonium removal efficiencies in 23 the order $\mathrm{Mg}^{2+}>\mathrm{Ca}^{2+}>\mathrm{K}^{+}$. The maximum exchange capacity in the fluidised bed studies of the original 24 Purolite C100E (bed height $27 \mathrm{~cm}$, resin weight $75 \mathrm{~g}$, initial ammonium concentration $17.4 \mathrm{mg} / \mathrm{L}$, 25 filtration velocity $0.5 \mathrm{~m} / \mathrm{h}$ ) was $10.48 \mathrm{mg} / \mathrm{g}$. It progressively reduced slightly after three regeneration 26 cycles to $8.79 \mathrm{mg} / \mathrm{g}$. The column breakthrough data satisfactorily fitted the Thomas model. A household 

$\mathrm{m} / \mathrm{h}$ in Vietnam successfully reduced the initial $6 \mathrm{mg} \mathrm{NH}{ }_{4}^{+} / \mathrm{L}$ in groundwater (after sand filter pretreatment) to well below the Vietnam drinking water standard ( $3 \mathrm{mg} / \mathrm{L})$ continuously for one week.

31 Keywords: Ammonium removal; Contaminated water; Ion exchange; Household water filter; Purolite

32 C100-E resin

\section{Introduction}

35 One of the most serious global problems currently facing humanity is the inability to provide clean water for drinking and other purposes. The lack of clean water is threatening the lives of billions of people in many countries around the world, especially in developing countries (Aliewi and Al-Khatib, 2015; Tanabe et al., 2001; Sica et al., 2014). Vietnam, a country in Southeast Asia, is no exception.

In Vietnam, clean water for drinking and living needs is provided from surface water (rivers, lakes, and streams), rainwater and groundwater. In many rural areas, groundwater is the main water source for human sustenance and daily activities. Groundwater is often exploited through dug wells or drilled wells,

42 pre-treated by filtering through sand filter tanks prior to use in households (Terin and Sabogal-Paz, 2019).

43 The quality of groundwater in each locality fluctuates very widely and is unstable, depending on many 44 factors including groundwater circuits, geological conditions and human activities. The groundwater 45 treated by a conventional sand filter normally still contains many pollutants such as arsenic, iron, 46 manganese, and ammonium, exceeding the permitted standard concentration limits. Among these 47 pollutants, ammonium is considered as one of the most common and difficult pollutants to eliminate ( $\underline{\mathrm{u}}$ 48 et al., 2017; Alshameri et al., 2014). In Hanoi (Vietnam), groundwater with high ammonium 49 concentrations of $55-70 \mathrm{mg} / \mathrm{L}$ were reported in some villages (Vietnam Environment Agency, 2016). In 50 another study conducted in three villages in Ha Nam Province of Vietnam, average groundwater 51 ammonium concentrations of $22-95 \mathrm{mg} / \mathrm{L}$ were detected in 2006 with some samples having values greater 52 than $150 \mathrm{mg} / \mathrm{L}$ (Nguyen et al., 2009). These values were 7 to 32 times higher than the Vietnam drinking 
water standard (3 mg/L, Vietnamese Department of Preventive Medicine \& Environment, 2009). Not only

54 Vietnam, but there are many other countries that have similar excessive levels of ammonium pollution in 55 their groundwater sources. Examples here include Dongting Plain, central China (Huang et al., 2021), 56 Bangladesh (Tanabe et al., 2001), Palestine (Aliewi and Al-Khatib, 2015), and Montana in the USA 57 (Shaw et al., 2013). Due to its toxicity to human health, ammonium in groundwater should be removed 58 and this is one of the major challenges the water treatment industry is currently facing.

59 There are several technologies that can remove ammonium from water such as biological 60 nitrification/denitrification, air stripping, chlorination, adsorption, ion exchange, and membrane processes 61 (Sica et al., 2014; Ding and Sartaj, 2016; Aral et al., 1999). Of these, ion exchange is known to be one of 62 the most widely applied technologies in removing ammonium (Tchobanoglous et al., 2014). In this 63 process, specific ions in solution displace ions of similar charge from an exchange material. The main 64 principle of this approach can be summarised for ammonium exchange on ion exchange resin employing 65 the following equation:

$$
\mathrm{R}-\mathrm{X}+\mathrm{NH}_{4}^{+} \leftrightarrow \mathrm{R}^{-\mathrm{NH}_{4}}+\mathrm{X}^{+}
$$

where $\mathrm{R}^{-}$is the anionic group of an ion exchange resin and $\mathrm{X}$ is the exchangeable cation neutralising the anionic charge.

Ion exchangers can be classified as natural materials (natural zeolite) and synthetic organic resins (Ding and Sartaj, 2016). Compared with natural zeolite, synthetic resins have many advantages, such as:

71 longer life cycle, faster exchange rate, better durability and higher exchange capacity (Ding and Sartaj, 72 2016; Aral et al., 1999). In groundwater, there are many coexisting ions such as calcium and magnesium 73 present along with ammonium and these ions can compete with ammonium for ion exchange. Such 74 competition will reduce efficiency in removing ammonium via an ion exchanger. Only a few studies 75 reported in the literature have evaluated the treatment efficiency of ammonium ions in not only water 76 sources generally, but also real groundwater in particular by ion exchange resins. Jorgensen and 77 Weatherley (2003) reported that Dowex 50W-X8 and Purolite MN500 ion exchange resins had the 78 maximum exchange capacity of approximately 35 and $29 \mathrm{mg} / \mathrm{g}$, respectively, at the initial concentration 
of $200 \mathrm{mg} \mathrm{NH}_{4}^{+} / \mathrm{L}$ synthetic solution. Ding and Sartaj (2016) reported that Amberlite IR120 H resin had a

80 Langmuir maximum exchange capacity of $29.76 \mathrm{mg} / \mathrm{L}$ at an initial concentration of 300-3000 $\mathrm{mg} \mathrm{NH}_{4}{ }^{+} / \mathrm{L}$

81 synthetic solution.

82 One of the most popular ion exchange resins used for water treatment in Vietnam is Purolite C100-E

83 resin (Purolite Co., UK). This resin is already in use not only in Vietnam but also in many other countries

84 for reducing the hardness of domestic water sources. To the best of the authors' knowledge, no study has

85 yet evaluated this resin for the treatment of ammonium in water. Therefore, this study was undertaken to

86 evaluate the additional advantage of Purolite C100-E ion exchange resin for ammonium removal from

87 groundwater. If the resin is found to be effective in removing ammonium, it can then serve two purposes,

88 namely, removing ammonium as well as water hardness, an advantage for the water treatment plants.

89 Another aspect of the study was the evaluation of continuous ammonium removal by the resin in a

90 dynamic column set-up, which can be applied to design practical groundwater treatment systems in rural

91 areas. The regeneration efficiency of the resin was also studied to obtain information on the reusability of

92 the resin which would reduce the treatment cost. Finally, the study was conducted in the field with real

93 contaminated groundwater containing competing cations at Ha Noi, Vietnam, in an effort to fully evaluate

94 the practical performance of Purolite C100E. The studies in dynamic columns with mathematical

95 modelling of ammonium breakthrough, and field testing of the resin performance in household conditions

96 are innovations researched in this paper.

97

$98 \quad$ 2. Materials and methods

$99 \quad$ 2.1. Ion exchange resin

100 The ion exchange resin used in this study was Purolite C100-E (obtained from Purolite Co.). Purolite

101 C100-E is a strong acid cation resin and structure-wise, it consists of gel polystyrene cross-linked with

102 divinylbenzene. The functional group of this resin is sulfonic acid $\left(-\mathrm{SO}_{3} \mathrm{H}\right)$, which contains the

103 exchangeable ion $\mathrm{Na}^{+}$. Purolite C100-E has a total exchange capacity of $1.90 \mathrm{eq} / \mathrm{L}\left(\mathrm{Na}^{+}\right.$form), moisture

104 retention of $46-50 \%$, particle size from 300 to $1200 \mu \mathrm{m}$ and density of $800-840 \mathrm{~g} / \mathrm{L}$. The resin was 
initially washed with distilled water to remove any dirt present in it. It was then dried at room temperature

$106\left(30 \pm 1^{\circ} \mathrm{C}\right)$ for $24 \mathrm{~h}$ to remove adsorbed moisture.

\subsection{Synthetic ammonium solution}

Ammonium stock solution of $2000 \mathrm{mg} \mathrm{NH}_{4}{ }^{+} / \mathrm{L}$ was prepared by dissolving $11.888 \mathrm{~g}$ analytical-grade $\mathrm{NH}_{4} \mathrm{Cl}$ (Merk Chemical Co.) in $2000 \mathrm{~mL}$ distilled water. Then, the stock solution was diluted with distilled water to achieve the desired ammonium concentrations (20 to $2000 \mathrm{mg} / \mathrm{L}$ ) for use in batch and 112 column experiments.

\subsection{Analytical methods}

115 The concentration of ammonium in the liquid phase was determined using a manual spectrometric method (ISO 7150/1-1984). Here, the blue compound formed by reaction of ammonium in solution with salicylate and hypochlorite ions in the presence of sodium nitrosopentacyanoferrate (11l) was measured by an UV-VIS spectrophotometer (Model 8453, Agilent Technologies, Inc., California, United States) at a wavelength of $655 \mathrm{~nm}$.

Scanning electron microscopy (SEM, Model JSM-7500F, JEOL Ltd., Japan) served to investigate the surface morphology of the Purolite C100E resin particles before and after the ion exchange process.

122 Meanwhile, the surface chemical elemental composition before and after the ion exchange process was 123 determined by Energy Dispersion Spectrometry analysis (EDS, Model X-max $50 \mathrm{~mm}^{2}$, Oxford 124 Instruments Analytical Ltd., England).

\subsection{Batch studies}

127 Several batch ion exchange experiments were conducted at room temperature of $30 \pm 1^{\circ} \mathrm{C}$ to evaluate 128 the performance of Purolite C100E for removing ammonium. 


\subsubsection{Effect of $p H$}

132 The effect of $\mathrm{pH}$ on ammonium removal by Purolite $\mathrm{C}-100 \mathrm{E}$ was studied at a range of $\mathrm{pH}$ values from 133 approximately 1 to 11 . Here the $\mathrm{pH}$ of synthetic ammonium solution of $50 \mathrm{mg} / \mathrm{L}$ was adjusted using $\mathrm{HCl}$ 134 and $\mathrm{NaOH}$ standard solutions to achieve the desired $\mathrm{pH}$ values. As the $\mathrm{pH}$ changed from 1 to 11 , the ionic 135 strength also changed. To keep the ionic strength constant as much as possible for the pH levels, this 136 experiment was repeated by adding $\mathrm{NaCl}$ to maintain the solutions at two ionic strength: $0.001 \mathrm{M}$ and $1370.01 \mathrm{M} \mathrm{NaCl} . \mathrm{NaCl}$ is an indifferent electrolyte, one that plays the role of a supporting medium to keep 138 ionic strength constant throughout all $\mathrm{pH}$ level values (Hedström and Amofah, 2008). The experiments 139 were conducted by adding $1.0 \mathrm{~g}$ resin to $100 \mathrm{~mL}$ synthetic ammonium solution containing $50 \mathrm{mg} \mathrm{NH}_{4}^{+} / \mathrm{L}$ 140 at different levels of $\mathrm{pH}$ in several $250 \mathrm{~mL}$ Erlenmeyer flasks. These flasks were agitated at $130 \mathrm{rpm}$ for $14124 \mathrm{~h}$. The suspensions were filtered through $0.45 \mu \mathrm{m}$ filter papers and the concentrations of ammonium in 142 the filtrates were measured as explained before.

\subsubsection{Kinetics experiment}

$1.0 \mathrm{~g}$ resin was added to $100 \mathrm{~mL}$ synthetic ammonium solution containing $50 \mathrm{mg} \mathrm{NH}_{4}^{+} / \mathrm{L}$ in several $250 \mathrm{~mL}$ Erlenmeyer flasks. These flasks were agitated at $130 \mathrm{rpm}$ and samples were collected after 0, 5, $10,15,30,45,60,90,120,180$ and 240 min from each flask. The samples were filtered through $0.45 \mu \mathrm{m}$ filter papers and the concentrations of ammonium in the filtered samples were measured.

\subsubsection{Equilibrium isotherm experiment}

\section{Effect of resin dose}

Synthetic water containing $50 \mathrm{mg} \mathrm{NH}{ }_{4}^{+} / \mathrm{L}$ at $\mathrm{pH} 6.5$ was used in this study. Different amounts of 153 Purolite C100-E were added to $100 \mathrm{~mL}$ of the synthetic ammonium solution in a set of $250 \mathrm{~mL}$ 154 Erlenmeyer flasks to produce concentrations from 0.5 to $20 \mathrm{~g}$ resin/L. The flasks were agitated in a shaker 155 at $130 \mathrm{rpm}$ for $24 \mathrm{~h}$. The supernatants from the suspensions in these flasks were filtered through $0.45 \mu \mathrm{m}$ 156 filter papers and the concentrations of ammonium in the filtrates were measured. 
$2.0 \mathrm{~g}$ resin was added to $100 \mathrm{~mL}$ synthetic ammonium solution to the different initial ammonium concentrations, ranging from 10 to $200 \mathrm{mg} / \mathrm{L}$, in a set of $250 \mathrm{~mL}$ Erlenmeyer flasks. The flasks were agitated in a shaker at $130 \mathrm{rpm}$ for $24 \mathrm{~h}$. The supernatants from the suspensions in these flasks were then filtered through $0.45 \mu \mathrm{m}$ filter papers and the concentrations of ammonium in the filtrates were measured.

Another experiment was conducted using the same procedure, but the initial ammonium concentration ranged from 50 to $2000 \mathrm{mg} / \mathrm{L}$, to determine whether the maximum exchange capacity of the resin calculated using standard adsorption models depends on the initial ammonium concentration range used.

165 The amount of ammonium in the solid phase was calculated using the mass balance Equation 1 166 (Wassie and Srivastava, 2016):

$$
Q_{\mathrm{e}}=\frac{\left(C_{o}-C_{e}\right) V}{m}
$$

where, $Q_{\mathrm{e}}$ is the mass of ammonium exchanged per unit mass of resin $(\mathrm{mg} / \mathrm{g}) ; C_{o}$ and $C_{e}$ are respectively; $V$ is the volume of solution (L) and $m$ is the mass of Purolite C100-E resin $(\mathrm{g})$.

171 The removal efficiency (RE, \%) of ammonium was calculated using Equation 2:

$172 \quad \operatorname{RE}(\%)=\frac{\left(C_{o}-C_{e}\right)}{C_{o}} \cdot 100(\%)$

\subsubsection{Effect of co-existing cations on ammonium removal}

175 Based on the Vietnamese National Environmental Report (2016) which covers the period 2011-2015, the groundwater in the northern delta region of Vietnam contains $\mathrm{Ca}$ and $\mathrm{Mg}$ ions content ranging from 177 56.23-57.62 $\mathrm{mg} \mathrm{Ca}{ }^{2+} / \mathrm{L}$ and 34.71-36.98 $\mathrm{mg} \mathrm{Mg}^{2+} / \mathrm{L}$, respectively. An experiment was conducted by 178 adding specifically potassium, calcium, and magnesium ions to the synthetic ammonium solution to 179 determine the effects of these ions on ammonium removal by the resin. A fixed concentration of each cation $(50 \mathrm{mg} / \mathrm{L})$ was added to water containing five ammonium concentrations, ranging from 10 to 50

$181 \mathrm{mg} / \mathrm{L}$. The experimental procedure is similar to the equilibrium isotherm experiment. 


\subsection{Fluidised bed experiment}

A fluidised bed experiment was conducted using a glass column of $22 \mathrm{~mm}$ internal diameter and 300 mm height. The column was packed with $75 \mathrm{~g}$ Purolite C100E, to have a height of $270 \mathrm{~mm}$. Synthetic ammonium solution $\left(\mathrm{C}_{\mathrm{o}} \approx 17 \mathrm{mg} \mathrm{NH}{ }_{4}^{+} / \mathrm{L}\right)$ prepared from tap water was pumped upwards through the column by dosing pumps with a constant flow rate of $200 \mathrm{~mL} / \mathrm{h}$ (corresponding to the filtration velocity of $0.5 \mathrm{~m} / \mathrm{h}$ ). The effluent samples were collected every $15 \mathrm{~min}$ for $238 \mathrm{~h}$ by an automatic sampling device and the solutions were analysed for ammonium (UV-VIS spectrophotometer, Model 8453, Agilent Technologies, Inc., California, USA) and other cations using an ICP-MS instrument (Model ELAN 9000, PerkinElmer, Inc., Shelton, USA).

The maximum amount of ammonium (mg) exchanged (removal) by the resin in the column was calculated using Equation 3 (Kalaruban et al., 2016):

$$
q_{\text {total }}=Q \cdot \int_{t=0}^{t-\text { total }} C_{i e} \cdot d t
$$

where, $q_{\text {total }}$ is the maximum amount of ammonium exchanged by the resin (mg), $Q$ is the flow rate of water $(\mathrm{L} / \mathrm{h}), t$ is the operation time $(\mathrm{h})$ and $C_{i e}$ is the exchanged ammonium concentration $\left(C_{i e}=C_{o}-C_{t}\right)$ $(\mathrm{mg} / \mathrm{L})$.

The maximum ion exchange capacity of the resin $\left(\mathrm{q}_{\mathrm{m}}, \mathrm{mg} / \mathrm{g}\right)$ was calculated from Equation 4 :

$$
q_{m}=\frac{q_{\text {total }}}{M}
$$

$$
\text { where } \mathrm{M} \text { is the mass of resin used }(\mathrm{g}) \text {. }
$$

\subsection{Fluidised bed column results modelling}

The Thomas model (Thomas, 1944) was used to predict the breakthrough curve and the maximum ion exchange capacity of the material for ammonium in the fluidised bed column (Aksu and Gönen, 2004). This model assumes plug flow behaviour in the bed, uses the Langmuir isotherm for equilibrium and second order reversible reaction for kinetics (Nur et al., 2014). The linearised form of the Thomas model can be expressed as follows (Thomas, 1944): 
where, $k_{T h}$ is the Thomas rate constant $(\mathrm{mL} / \mathrm{min} \mathrm{mg}) ; q_{o}$ is the equilibrium ammonium uptake per $\mathrm{g}$ of resin $\left(\mathrm{mg} \mathrm{NH} \mathrm{NH}_{4}{ }^{+} / \mathrm{g}\right) ; C_{o}$ is the inlet ammonium concentration $(\mathrm{mg} / \mathrm{L}) ; C_{t}$ is the outlet ammonium concentration at time $\mathrm{t}(\mathrm{mg} / \mathrm{L}) ; M$ is the mass of resin $(\mathrm{g})$; and $Q$ is the filtration rate $(\mathrm{mL} / \mathrm{min})$ and $t$ stands for filtration time (min).

The Thomas rate constant $k_{T h}$ and the ammonium exchange capacity of the bed $q_{o}$ can be determined from a plot of $\ln \left[\left(C_{d} / C\right)-1\right]$ against time $(\mathrm{t})$.

\subsection{Regeneration of the resin used in the fluidised bed experiment}

Regeneration of the exhausted Purolite C100E after fluidised bed experiment was done by desorbing the adsorbed ammonium using 10\% sodium chloride solution. Based on the Purolite Engineering Bulletin document (2013), this process was operated in counter-flow mode (up-flow mode), and it comprised 3 steps as follows. Firstly, the regenerant brine was prepared by dissolving $100 \mathrm{~g}$ Indian industrial sodium chloride salt in $1 \mathrm{~L}$ of distilled water to create a solution of $10 \% \mathrm{NaCl}$. This brine was pumped up-flow through the column at a rate of $2 \mathrm{BV} / \mathrm{h}(200 \mathrm{~mL} / \mathrm{h})$ for one hour. In the second step, a slow rinsing process was carried out using distilled water at the same flow rate as the first step for one hour. This removed the excess solution phase sodium (unadsorbed) inside the resin. In the third step, a final rinse with distilled water was carried out at the experimental flow rate to achieve the same initial condition prior to the fluidised bed experiments. This process was conducted for about 20 minutes.

\subsection{Field trial at Hanoi, Vietnam}

A full-scale household filter cartridge was designed and used in an experiment with real contaminated groundwater at Hoang Mai district, Ha Noi, Vietnam for the removal of ammonium. Before using the 
contaminants in raw groundwater has been confirmed by various studies (Sabogal-Paz et al., 2020;

231 Nitzsche et al., 2015). The concentrations of contaminants in groundwater before and after the

232 pretreatment with the sand filter are shown in Table 1. Although the sand filter removed a high percentage

233 of all the contaminants, the ammonium concentration in the treated water was still above the maximum

234 permitted concentration limit of Vietnam $(3 \mathrm{mg} / \mathrm{L})$. Therefore, the pretreated water required further 235 treatment and the resin was used to investigate this.

236

237 Table 1 - Contaminants in raw groundwater and after sand filtration

\begin{tabular}{lcc}
\hline Contaminant & Raw groundwater & After sand filter \\
\hline As $(\mu \mathrm{g} / \mathrm{L})$ & 78.8 & 1.4 \\
$\mathrm{Fe}(\mathrm{mg} / \mathrm{L})$ & 23 & $<0.05$ \\
$\mathrm{NH}_{4}^{+}(\mathrm{mg} / \mathrm{L})$ & 25.73 & 5.92 \\
Permanganate $(\mathrm{mg} / \mathrm{L})$ & 1.72 & 1.29 \\
\hline
\end{tabular}

239 The household filter cartridge used in this trial was fabricated from a PAC water pipe. It had an 240 internal diameter of $10 \mathrm{~cm}$ containing $4 \mathrm{~kg}$ of Purolite C100E resin (corresponding to a bed height of 241 about $80 \mathrm{~cm}$ ). The pretreated groundwater was pumped downward through the cartridge at a constant 242 flow rate of $15 \mathrm{~L} / \mathrm{h}$ (corresponding to a filtration velocity of $1.9 \mathrm{~m} / \mathrm{h}$ ). Water samples were collected after 243 every $12 \mathrm{~h}$ for one week and analysed for ammonium, zinc, manganese, iron, calcium, magnesium, and 244 sodium using an ICP-MS instrument (Model ELAN 9000, PerkinElmer, Inc., Shelton, USA). 


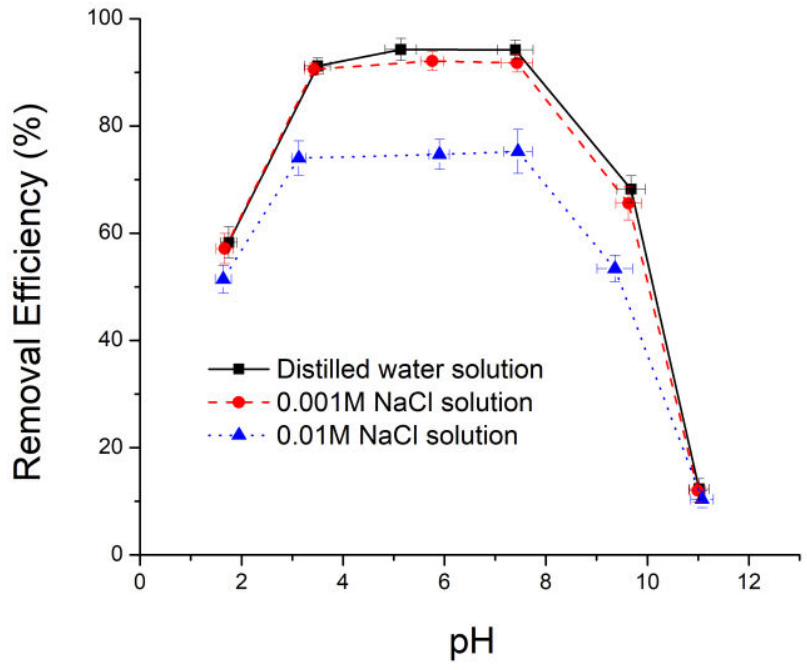

(a)

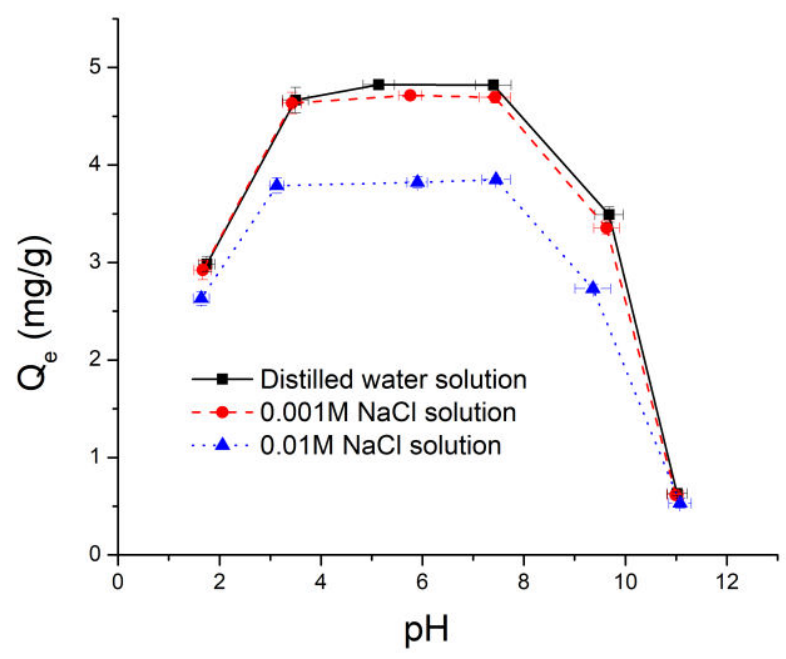

(b)

Fig. 1 - Effect of $\mathrm{pH}$ on (a) ammonium removal efficiency and (b) amount of ammonium removed (mg) per $\mathrm{g}$ resin $\left(Q_{\mathrm{e}}\right)$ at three ionic strengths (Experimental conditions: resin dose $=10 \mathrm{~g} / \mathrm{L}$; initial $\mathrm{NH}_{4}{ }^{+}$ concentration $=50 \mathrm{mg} / \mathrm{L}$ )

The data on the effect of $\mathrm{pH}$ on ammonium removal illustrated that the maximum removal efficiency occurred between $\mathrm{pH} 3$ and 8 for all three ionic strength solutions (Fig. 1). When the pH was less than 3, the adsorption capacity was lower $(<4 \mathrm{mg} / \mathrm{g})$, which is explained by the competition between $\mathrm{H}^{+}$in the highly acidic condition of the solution with $\mathrm{NH}_{4}{ }^{+}$ions for exchange (Vu et al., 2017).

The decline in ammonium removal efficiency was also observed when the $\mathrm{pH}$ was higher than 8 . This is because at higher levels of $\mathrm{pH}, \mathrm{NH}_{4}{ }^{+}$ions are converted to an un-ionised form $\left(\mathrm{NH}_{3}\right)$ from having a reaction with the large amounts of $\mathrm{OH}^{-}$ions generated (Aral et al., 1999). The higher levels of $\mathrm{pH}$ produced in this experiment were due to additions of $\mathrm{NaOH}$ for increasing the $\mathrm{pH}$ of the solution. The $\mathrm{Na}$ added here would have competed with ammonium for cation exchange on the resin during these higher 
263 levels of $\mathrm{pH}$ resulting in reduced ammonium removal. However, the reduction in ammonium removal 264 occurred even in solutions having $0.01 \mathrm{M} \mathrm{NaCl}$ where the $\mathrm{Na}$ concentration was nearly the same for any 265 level of $\mathrm{pH}$. This shows that $\mathrm{Na}$ competition with ammonium for exchange on the resin is not the major 266 cause for the decline in ammonium removal at higher levels of $\mathrm{pH}$, but ammonium conversion to ammonia 267 is the main reason for this. Based on these results, the initial $\mathrm{pH}$ value of the subsequent experiments was 268 maintained at 6.5 to obtain larger amounts of ammonium being removed.

269 Compared with the distilled water solution containing $\mathrm{NH}_{4}{ }^{+}$(no addition of $\mathrm{NaCl}$ ), the ammonium 270 removal efficiency and the equilibrium exchange capacity $\left(Q_{\mathrm{e}}\right)$ in the solution with $0.01 \mathrm{M} \mathrm{NaCl}$

271 diminished considerably (Fig. 1). This is due to $\mathrm{Na}^{+}$ions in the latter solution competing with $\mathrm{NH}_{4}{ }^{+}$ions 272 for ion exchange in the resin (Aral et al., 1999). This competition is much less marked in the $0.001 \mathrm{M}$ $273 \mathrm{NaCl}$ solution due to the smaller concentration of $\mathrm{Na}^{+}$in this solution.

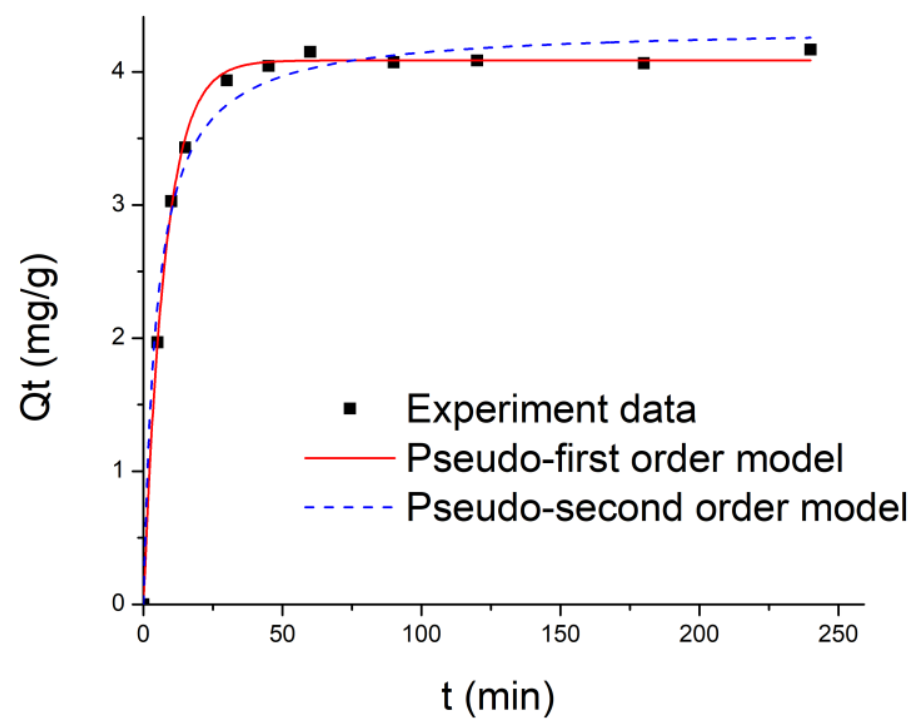

277 Fig. 2 - Pseudo-first order and Pseudo-second order model prediction of the kinetics of ammonium removal by the resin (Experimental conditions: resin dose $=10 \mathrm{~g} / \mathrm{L} ; \mathrm{NH}_{4}{ }^{+}$initial concentration $=50 \mathrm{mg} / \mathrm{L}$ ) 
280 it reduced, and the exchange process reached equilibrium after $45 \mathrm{~min}$. Sica et al. (2014) also reported a

281 short time for the exchange of ammonium on Purolite $\mathrm{C} 150 \mathrm{H}$ resin to reach equilibrium (40 min). Three

282 common kinetic models were applied to describe the kinetics of ammonium removal by Purolite C100-E

283 resin from the solution, namely, Elovich (Li et al., 2009), Pseudo-first order (Tseng et al., 2009), and

284 Pseudo-second order (Kumar and Sivanesan, 2006). To determine the model that best fitted the data, non-

285 linear regression analysis was applied. Table 2 presents the non-linearised equations of the three kinetic

286 models, their parameters and coefficient of determinations $\left(\mathrm{R}^{2}\right)$ for the data best fitting to the models.

287 Table 2 - Kinetic models applied and parameters and coefficient of determinations $\left(\mathrm{R}^{2}\right)$ obtained from the 288 model fits to the data

\begin{tabular}{lllll}
\hline Model & $\begin{array}{l}\text { Non-linearised } \\
\text { equation }\end{array}$ & $\mathrm{R}^{2}$ & Parameters & Equation description \\
\hline $\begin{array}{l}\text { Pseudo- } \\
\text { first } \\
\text { order }\end{array}$ & $q_{t}=q_{e} \cdot\left(1-e^{-k_{1} t}\right)$ & 0.9983 & $q_{e}=4.08$ & $\begin{array}{l}t \text { is the contact time }(\mathrm{min}) ; q_{t} \text { is } \\
k_{l}=0.1299\end{array}$ \\
& & $\begin{array}{l}\text { the amount of ammonia ion } \\
\text { removed per } \mathrm{g} \text { of resin at time } \mathrm{t} \\
(\mathrm{mg} / \mathrm{g}) ; q_{e} \text { is the } q_{t} \text { value at } \\
\end{array}$ & & $\begin{array}{l}\text { equilibrium }(\mathrm{mg} / \mathrm{g}) ; k_{l} \text { is the rate } \\
\text { constant of pseudo-first order } \\
\text { expression }\left(\mathrm{min}^{-1}\right)\end{array}$
\end{tabular}

\begin{tabular}{|c|c|c|c|c|}
\hline $\begin{array}{l}\text { Pseudo- } \\
\text { second } \\
\text { order }\end{array}$ & $q_{t}=\frac{k_{2} q_{e}^{2} t}{1+k_{2} q_{e} t}$ & 0.9866 & $\begin{array}{l}q_{e}=4.33 \\
k_{2}=0.04907\end{array}$ & $\begin{array}{l}k_{2} \text { is the rate constant of pseudo- } \\
\text { second order expression ( } \mathrm{g} / \mathrm{mg} \\
\mathrm{min})\end{array}$ \\
\hline
\end{tabular}

$\begin{array}{lll}\text { Elovich } !_{t}=\frac{1}{\beta} \ln (1+\alpha \beta t) & 0.9249 & \begin{array}{l}\alpha=24.01 \\ \beta=2.08\end{array}\end{array} \begin{aligned} & \alpha \text { is the initial adsorption rate } \\ & (\mathrm{mg} / \mathrm{g} \mathrm{min}) ; \beta \text { is the desorption } \\ & \text { constant }(\mathrm{g} / \mathrm{mg})\end{aligned}$

290 As can be seen from Table 2, both Pseudo-first order and Pseudo-second order models had higher $\mathrm{R}^{2}$ 291 values $\left(0.9983\right.$ and 0.9866 , respectively) compared to the Elovich model $\left(\mathrm{R}^{2}=0.9249\right)$. It means that these 292 models can describe the kinetics of ammonium exchange. The comparison between experimental data and 


\subsubsection{Effect of resin dose and equilibrium exchange isotherms}

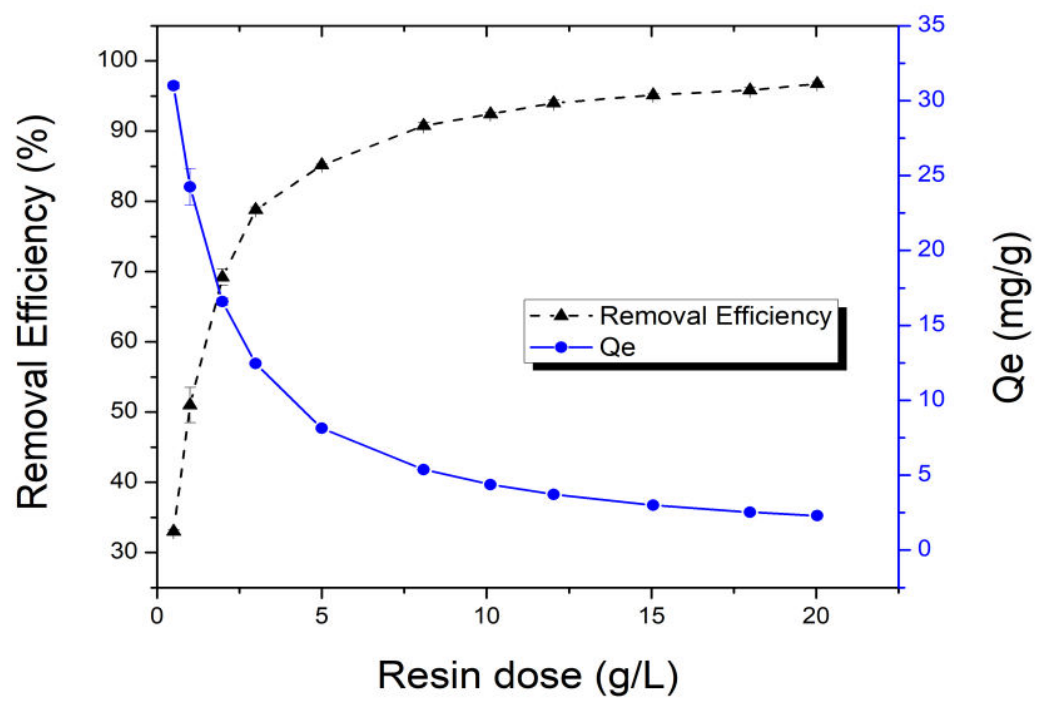

297

298

299

300

301

302

303

304

305

306

307

308

309

Fig. 3 - Effect of resin dose on the removal efficiency of ammonium and amount exchanged $\left(Q_{\mathrm{e}}\right)$ (Experimental conditions: resin doses: 02 - $20 \mathrm{~g} / \mathrm{L} ; \mathrm{NH}_{4}{ }^{+}$initial concentration: $50 \mathrm{mg} / \mathrm{L} ; 24 \mathrm{~h}$ shaking)

\section{As can be seen from Fig. 3, the removal efficiency of ammonium increased drastically when the resin} dose rose, and beyond the resin dose of $10 \mathrm{~g} / \mathrm{L}$, the removal efficiency became almost constant at about $90 \%$. The reason for the removal efficiency reaching a maximum of $90 \%$ and remaining almost constant is that nearly all ammonium in solution was removed by the resin. Based on this result a dose of $10 \mathrm{mg} / \mathrm{L}$ was chosen as the optimum resin dose for the subsequent experiments.

Two common isotherm models (Langmuir and Freundlich) were implemented to evaluate the equilibrium ammonium adsorption properties of the resin. The mathematical equation of Langmuir isotherm (Langmuir, 1918) is given below (Equation 6):

$$
Q_{e}=\frac{K b C_{e}}{1+K C_{e}}
$$


where $Q_{\mathrm{e}}$ is the mass of ammonium exchanged onto solid phase per unit mass of resin at equilibrium

$311(\mathrm{mg} / \mathrm{g}) ; K(\mathrm{~L} / \mathrm{mg})$ and $b(\mathrm{mg} / \mathrm{g})$ are Langmuir constants; and $C_{e}$ is equilibrium concentration of ammonium 312 in solution $(\mathrm{mg} / \mathrm{L})$.

313 The Freundlich isotherm equation (Freundlich, 1906) is presented below (Equation 7):

$314 \quad Q_{\mathrm{e}}=K_{f} C_{e}^{1 / n}$

315 where $Q_{\mathrm{e}}$ is the mass of ammonium exchanged onto solid phase per unit mass of resin at equilibrium $316(\mathrm{mg} / \mathrm{g}) ; C_{e}$ is the equilibrium concentration of ammonium in solution $(\mathrm{mg} / \mathrm{L}) ; K_{f}$ is Freundlich capacity 317 factor $\left((\mathrm{mg} / \mathrm{g})(\mathrm{L} / \mathrm{mg})^{1 / \mathrm{n}}\right)$; and $1 / \mathrm{n}$ is Freundlich intensity parameter.

$318 \quad$ Fig. 4 shows the prediction curves for the adsorption when Langmuir and Freundlich isotherm models 319 were fitted to data compared to actual experimental data. As can be seen from Table 3 , both models fitted 320 to the data very well with Freundlich isotherm model providing a slightly better fit $\left(\mathrm{R}^{2}=0.9936\right)$ 321 compared to Langmuir isotherm model $\left(\mathrm{R}^{2}=0.9752\right)$. The maximum adsorption capacity $\left(Q_{\max }\right)$ of the 322 resin calculated from the coefficient $b$ in Langmuir equation is $18.37 \mathrm{mg} / \mathrm{g}$. This value is lower than the 323 values reported by others for Amberlite IR120 H resin (29.76 mg/g) (Ding and Sartaj, 2016) and for 324 Purolite MN500 (approximately $26 \mathrm{mg} / \mathrm{g}$ ) and Dowex 50w-x8 (approximately $35 \mathrm{mg} / \mathrm{g}$ ) (Jorgensen and 325 Weatherley, 2003). This outcome is also slightly lower than those reported for few other materials (Table 326 4). The higher values obtained by others emerge mostly because they used much higher solution 327 concentrations of ammonium in their experiments (up to $3000 \mathrm{mg} \mathrm{NH}_{4}^{+} / \mathrm{L}$ ) which are not relevant to field 328 conditions ( $\underline{\text { Table 4) }}$ compared to the concentrations used in the current experiment on Purolite C100E (10 329 to $200 \mathrm{mg} \mathrm{NH}_{4}^{+} / \mathrm{L}$ ). In addition, the equilibrium time of Purolite MN500 and Dowex 50w-x8 (Jorgensen 330 and Weatherley, 2003) was much higher (4 days) compared to the Purolite C100E resin in the current 331 experiments (only $45 \mathrm{~min}$ ). Using higher solution concentrations would give higher Langmuir maximum 332 exchange capacity. This has been proved in the second adsorption experiment conducted where the initial 333 ammonium concentrations were increased to a range of 50 to $2000 \mathrm{mg} / \mathrm{L}$ and this increased the Langmuir 334 maximum exchange capacity of Purolite C100E to $40.16 \mathrm{mg} / \mathrm{g}$. This value is higher than that of Amberlite 
336 Weatherley, 2003) under the same test conditions (at high initial ammonium concentrations).

337 The favourable nature of ammonium adsorption on Purolite C100E was investigated from the K value 338 of the Langmuir isotherm model (Table 3) using a dimensionless constant $\mathrm{R}_{\mathrm{L}}$ according to the following 339 equation:

$$
R_{L}=\frac{1}{1+\left(1+K \cdot C_{o}\right)}
$$

341 where $C_{o}$ is the maximum initial ammonium concentration. The calculated $\mathrm{R}_{\mathrm{L}}$ value of 0.05 lies between 0 and 1 , indicating that the adsorption process is favourable (unfavourable $\left(R_{L}>1\right)$, favourable $(0$ $\left.343<\mathrm{R}_{\mathrm{L}}<1\right)$ or irreversible $\left(\mathrm{R}_{\mathrm{L}}=0\right.$ ) (Demir et al., 2008; Rusmin et al., 2015). The value of the Freundlich intensity parameter $1 / \mathrm{n}(0.4433$, Table 3$)$ also lies between 0 and 1 , indicating again a favourable adsorption process (guyen et al., 2020). It is consistent with the conclusion derived from the Langmuir model.

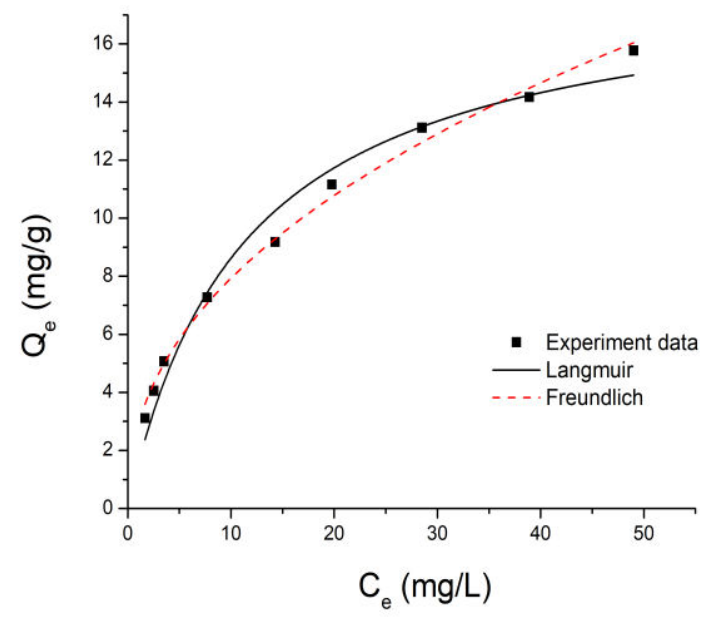

348 Fig. 4 - Equilibrium data for ammonium removal using the resin fitted to the Langmuir and Freundlich 349 isotherms 
351 Table 3 - Parameters of Langmuir and Freundlich isotherms and coefficient of determination $\left(\mathrm{R}^{2}\right)$ for 352 model fits

\begin{tabular}{ccc}
\hline & Parameter values & $\mathrm{R}^{2}$ \\
\hline Langmuir parameters & & \\
$\mathrm{K}(\mathrm{L} / \mathrm{mg})$ & 0.0883 & 0.9752 \\
$\mathrm{~b}(\mathrm{mg} / \mathrm{g})$ & 18.37 & \\
Freundlich parameters & & \\
$\mathrm{K}\left((\mathrm{mg} / \mathrm{g})(\mathrm{L} / \mathrm{mg})^{1 / \mathrm{n}}\right)$ & 2.8567 & 0.9936 \\
$1 / \mathrm{n}$ & 0.4433 & \\
\hline
\end{tabular}

353

354 Table 4 - Comparison of ammonium adsorption capacities of some natural and synthetic materials $\left(\mathrm{C}_{\mathrm{o}}\right.$ is 355 initial ammonium concentration; $\mathrm{Q}_{\max }$ is Langmuir maximum adsorption capacity)

\begin{tabular}{lccccc}
\hline Material & Solution & $\mathrm{C}_{\mathrm{o}}$ & $\mathrm{Q}_{\max }$ & Contact & Reference \\
& $\mathrm{pH}$ & $(\mathrm{mg} / \mathrm{L})$ & $(\mathrm{mg} / \mathrm{g})$ & time & \\
\hline Purolite C100E & 6.5 & $10-200$ & 18.37 & $45 \mathrm{~min}$ & This study \\
Purolite C100E & 6.5 & $50-2000$ & 40.16 & 45 min & This study \\
Amberlite IR120 H & 6.0 & $300-3000$ & 29.76 & 30 min & Ding and Sartaj (2016) \\
Purolite MN500 & - & $0-1000$ & $\approx 35$ & 4 days & $\underline{\text { Jorgensen and Weatherley (2003) }}$ \\
Dowex 50w-x8 & - & $0-1000$ & $\approx 26$ & 4 days & $\underline{\text { Jorgensen and Weatherley (2003) }}$ \\
Clinoptilolite & - & $0-1000$ & $\approx 19$ & 4 days & $\underline{\text { Jorgensen and Weatherley (2003) }}$ \\
Modified activated & $8.0-9.0$ & $685-735$ & 19.34 & 20 min & $\underline{\text { Halim et al. (2013) }}$ \\
carbon with HNO 3 & & & & &
\end{tabular}


358

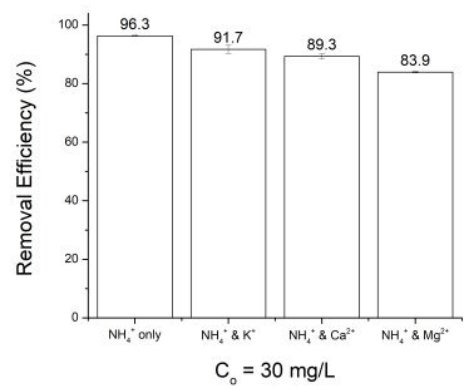

(c)

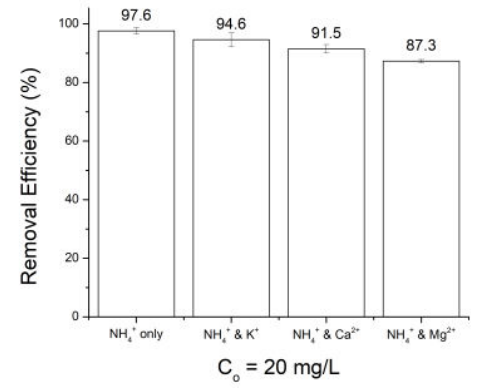

(b)

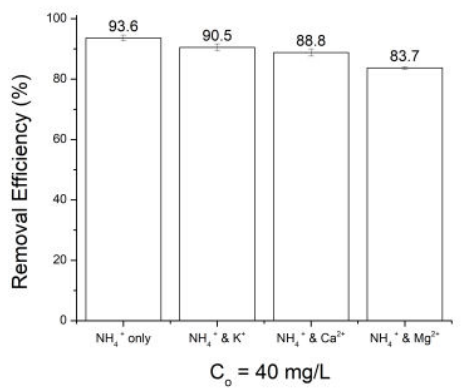

(d)

364 Fig. 5 - Ammonium removal efficiency in the presence of potassium, calcium and magnesium ions at 365 initial $\mathrm{NH}_{4}{ }^{+}$concentrations of (a) 10, (b) 20, (c) 30, (d) 40, and (e) $50 \mathrm{mg} / \mathrm{L}$ (resin dose $=10 \mathrm{~g} / \mathrm{L}$ ) the percentage of ammonium being removed. The decrease followed the order, $\mathrm{K}^{+}<\mathrm{Ca}^{2+}<\mathrm{Mg}^{2+}$, which is 
$370 \mathrm{~K} / \mathrm{L}$, respectively), although the same weight concentrations were used (50 $\mathrm{mg} / \mathrm{L})$. It is well known that in

371 the ion exchange process the affinity order of exchange between ions depends on their respective ion

372 concentrations expressed as number of equivalents of ions per unit volume of solution and charge on the

373 ion. Higher the charge on the ion the greater the affinity of the resin to the ion. Therefore, another reason

374 for the lowest degree of competition by $\mathrm{K}^{+}$is the monovalent nature of this cation compared to the other 375 two cations which are divalent. However, ammonium being a monovalent ion, was still significantly 376 adsorbed on the resin in the presence of divalent cations, calcium and magnesium. The likely reason for 377 this is that ammonium has a smaller hydrated ionic radius $(0.331 \mathrm{~nm})$ compared to calcium $(0.412 \mathrm{~nm})$ 378 and magnesium $(0.428 \mathrm{~nm}$ ) ions (Volkov et al., 1997), which helped ammonium ions to make closer and 379 better contact with the charged sites of the resin.

380 In addition to this, there would have been hydrogen bonding between the hydrogen atoms in 381 ammonium and oxygen atoms in the resin helping this stronger adsorption. It can be seen that at low 382 concentrations of ammonium, the influence of each competing ion on ammonium removal is minimal 383 because the ion exchange capacity of the material (approximately $20 \mathrm{meq} / \mathrm{L}$ solution based on the 384 manufacturer's value of $1.9 \mathrm{eq} / \mathrm{L}$ resin and $10 \mathrm{~g}$ resin/L solution used in the experiment) was not fully 385 utilised by the cations (not all $\mathrm{Na}^{+}$in the resin was exchanged). This means that the material can 386 simultaneously exchange/remove both ammonium and co-ions without much competition between them. 387 As the concentration of ammonium in the solution increased, the presence of competing ions reduced 388 ammonium removal by a slightly higher percentage, due to greater competition for the limited exchange 389 sites. 


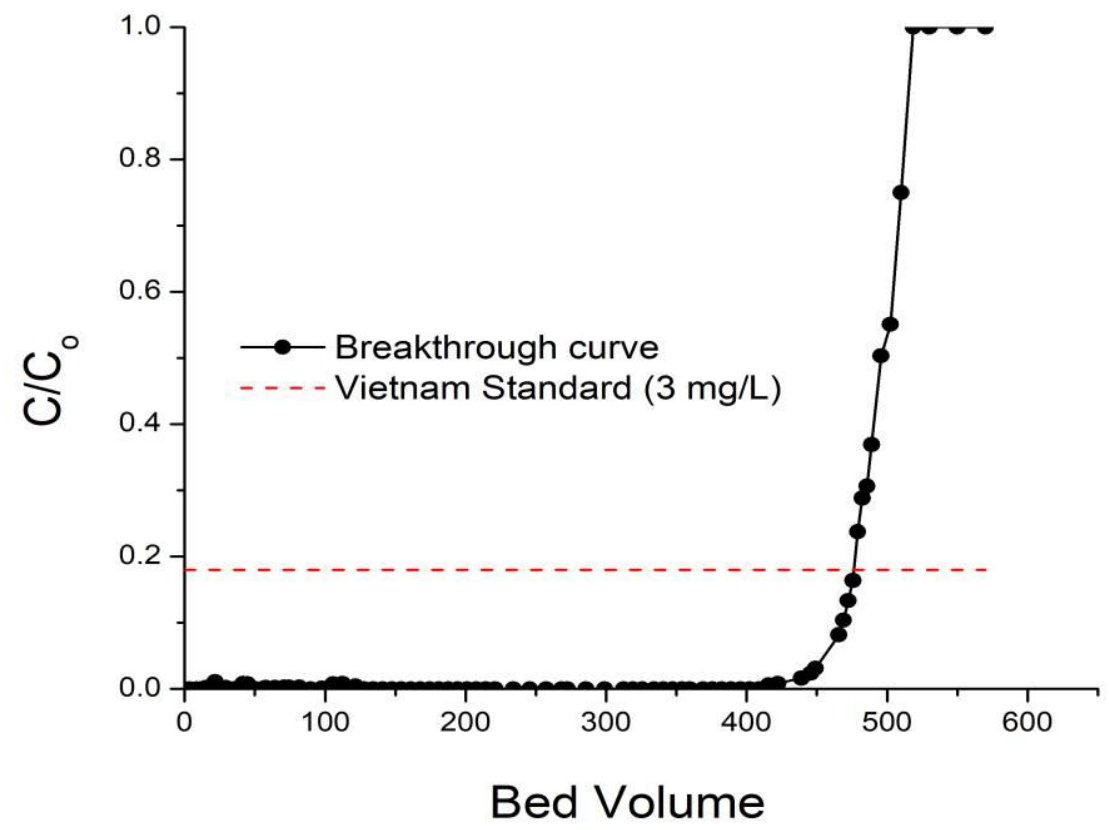

Fig. 6 - Breakthrough curve for ammonium removal by Purolite C100-E resin in the fluidised bed study (Experimental conditions: resin weight: $75 \mathrm{~g}$; influent ammonium concentration: $17.4 \mathrm{mg} / \mathrm{L}$; filtration velocity: $0.5 \mathrm{~m} / \mathrm{h}$; horizontal dotted line represents Vietnam's ammonium concentration permissible limit 397 for drinking water of $3 \mathrm{mg} / \mathrm{L}$ )

Table 5 - Influent and effluent concentrations of other ions in solution

\begin{tabular}{ccccccc}
\hline Metal ions & $\mathrm{Zn}(\mathrm{mg} / \mathrm{L})$ & $\mathrm{Mn}(\mathrm{mg} / \mathrm{L})$ & $\mathrm{Fe}(\mathrm{mg} / \mathrm{L})$ & $\mathrm{Ca}(\mathrm{mg} / \mathrm{L})$ & $\mathrm{Mg}(\mathrm{mg} / \mathrm{L})$ & $\mathrm{Na}(\mathrm{mg} / \mathrm{L})$ \\
\hline Influent & 0.07 & 0.022 & 0.25 & 20.2 & 10.8 & 0.216 \\
Effluent & 0.01 & 0.001 & 0.08 & 0.08 & 0.04 & 1.23 \\
\hline
\end{tabular}

Fig. 6 depicts the breakthrough curve for ammonium removal by Purolite C100-E resin in the fluidised

402 bed study. For the influent ammonium concentration of $17.4 \mathrm{mg} / \mathrm{L}$, the total ammonium exchange during 403 the operation time of $238 \mathrm{~h}(476 \mathrm{BV})$ was $786.35 \mathrm{mg}$ which gives a maximum ion exchange capacity 
$404\left(\mathrm{Q}_{\max }\right)$ of $10.48 \mathrm{mg} / \mathrm{g}$. This value is much higher than the column adsorption capacity of $3.3 \mathrm{mg} / \mathrm{g}$ reported 405 for a zeolite (clinoptilolite) packed in column with a height $20 \mathrm{~cm}$ for the removal of ammonium from a 406 wastewater containing an ammonium concentration of $20 \mathrm{mg} / \mathrm{L}$ at a similar flow velocity $(0.69 \mathrm{~L} / \mathrm{h})$ 407 (Hedström and Amofah, 2008).

408 The maximum ammonium exchange capacity value in the fluidised bed study is lower than the batch 409 Langmuir maximum capacity value for ammonium $\left(\mathrm{Q}_{\max }=18.37 \mathrm{mg} / \mathrm{g}\right)$. One reason for this is that the 410 synthetic solution used in the experiment was prepared from tap water, which contained many other metal 411 ions competing with ammonium for exchange on the resin. Table 5 shows the initial and effluent 412 concentrations of some of the co-ions in the synthetic solution. As can be seen from this table, $\mathrm{Ca}^{2+}$ and $413 \mathrm{Mg}^{2+}$ concentrations decreased significantly after the solution passed through the column containing the 414 resin indicating that they have occupied the exchange sites in place of ammonium. The increase in $\mathrm{Na}^{+}$in 415 the effluent is due to $\mathrm{Na}^{+}$ions in the resin exchanging with ammonium and other cations in the solution 416 and entering the solution.

417 Another reason for the poorer ammonium exchange capacity obtained in the fluidised bed study 418 compared to the batch Langmuir maximum capacity value is because: firstly, in the batch experiment, the 419 exchange process reached equilibrium; and secondly, the Langmuir model predicted the maximum 420 exchange capacity at a higher ammonium concentration in solution. These conditions were different in the 421 fluidised bed experiment, where the exchange capacity was measured at lower ammonium concentration, 422 and the exchange process did not reach equilibrium.

423 The fluidised bed ammonium ion exchange data fitted very satisfactorily to the Thomas model $\left(\mathrm{R}^{2}=\right.$ 424 0.9858). The $k_{T h}$ value obtained from the model fit was $0.1120(\mathrm{ml} / \mathrm{min} \mathrm{mg})$ and the ammonium uptake per $425 \mathrm{~g}$ of resin $\left(q_{o}\right)$ was $11.71 \mathrm{mg} / \mathrm{g}$. This $q_{o}$ value is approximately the same as that calculated manually from 426 the experimental data $\left(Q_{\max }=10.48 \mathrm{mg} / \mathrm{g}\right)$. 


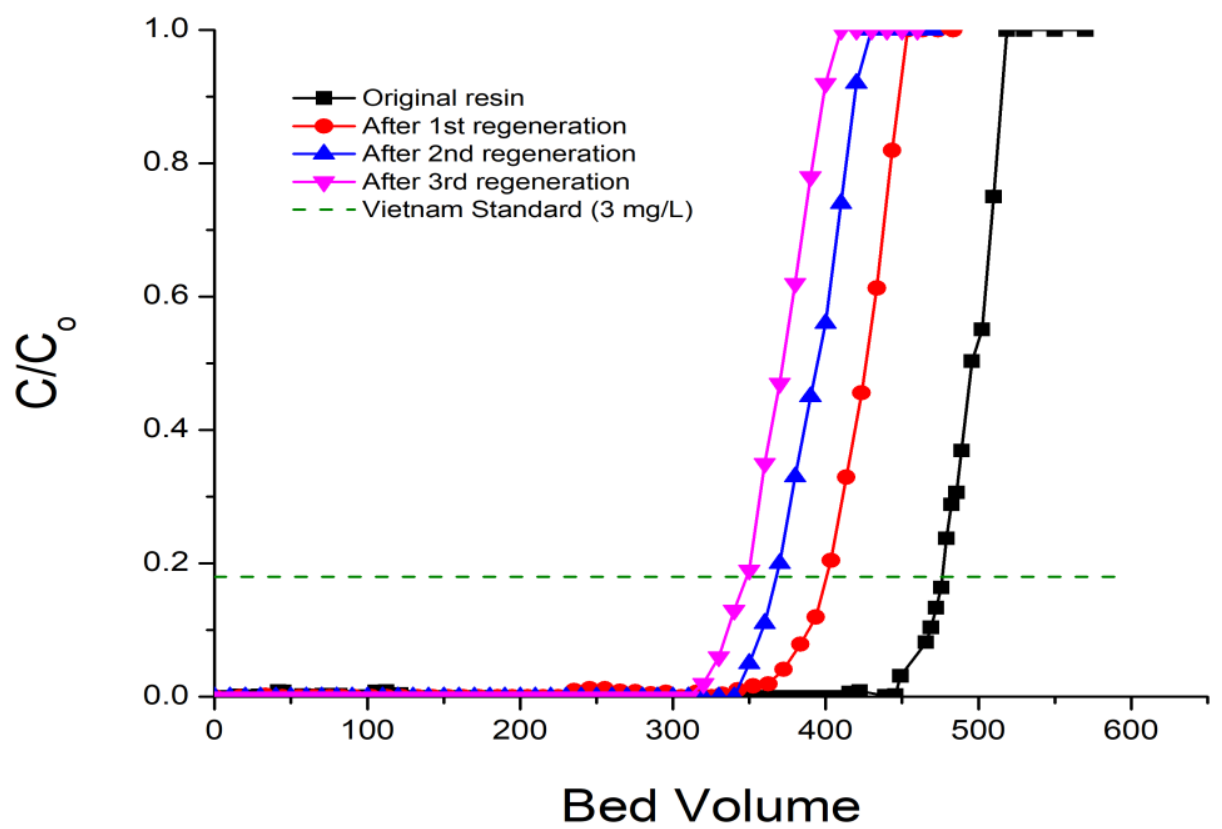

431 Fig. 7 - Breakthrough curves for ammonium regeneration by $10 \% \mathrm{NaCl}$ solution in the fluidised bed study 432 (bed height $=27 \mathrm{~cm}$, resin weight $=75 \mathrm{~g}$, initial ammonium concentration $=17.4 \mathrm{mg} / \mathrm{L}$, filtration velocity $433=0.5 \mathrm{~m} / \mathrm{h}$ ) for three ion exchange - regeneration cycles of Purolite C100E

Table 6 - Comparison of the performance of original and regenerated Purolite C100E (volume of water treated was calculated as the volume of effluent passed through the column before reaching the Vietnam's

437 ammonium concentration permissible limit for drinking water, resin weight $=75 \mathrm{~g}$ )

\begin{tabular}{lcccc}
\hline & $\begin{array}{c}\text { Total ammonium } \\
\text { exchange }(\mathrm{mg})\end{array}$ & $\begin{array}{c}\text { Exchange capacity } Q_{\mathrm{e}} \\
(\mathrm{mg} / \mathrm{g})\end{array}$ & $\begin{array}{c}\text { Volume } \\
\text { treated }(\mathrm{L})\end{array}$ & $\begin{array}{c}\text { Volume treated per kg } \\
\text { material }(\mathrm{L} / \mathrm{kg})\end{array}$ \\
\hline Original resin & 786.35 & 10.48 & 47.6 & 634.7 \\
After $1^{\text {st }}$ cycle & 711.75 & 9.49 & 45.4 & 605.3 \\
After $2^{\text {nd }}$ cycle & 684.44 & 9.12 & 43.0 & 573.3 \\
After $3^{\text {rd }}$ cycle & 659.90 & 8.79 & 41.0 & 546.7 \\
\hline
\end{tabular}



that the ammonium adsorbed on the resin after each cycle decreased as shown by the shift in the 440 breakthrough curves to lower bed volumes (to the left-hand side) in Fig. 7. Therefore, the maximum 441 exchange capacity for ammonium $\left(\mathrm{Q}_{\mathrm{m}}\right)$ of the resin in the column dropped progressively after each cycle.

442 In the first cycle, the $\mathrm{Q}_{\mathrm{m}}$ value decreased by $9.4 \%$ (from 10.48 to $9.49 \mathrm{mg} / \mathrm{g}$ ). Nevertheless, the exchange 443 capacity is still higher than many other materials (Hedström and Amofah, 2008), indicating that Purolite $444 \mathrm{C} 100 \mathrm{E}$ resin can potentially eliminate ammonium in solutions having co-ions and is reusable for at least 445 three times, thus reducing the cost of treatment.

446

\subsection{Field trial with real contaminated water}

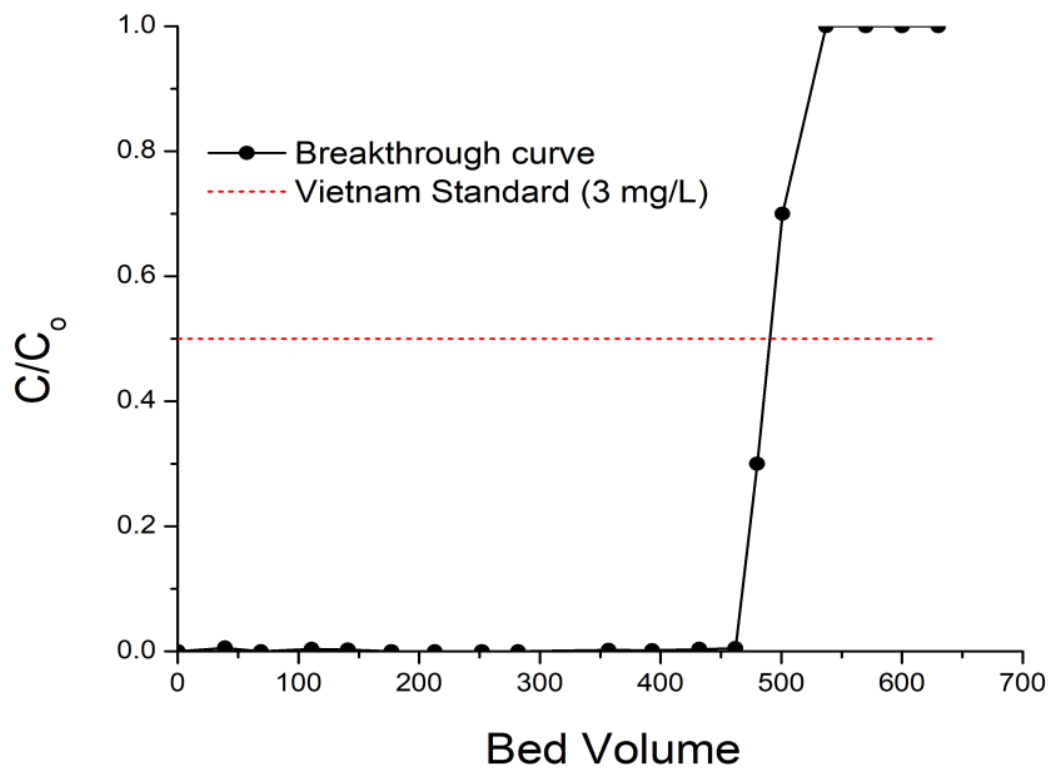

449 Fig. 8 - Breakthrough curve for ammonium removal by Purolite C100-E resin in the household filter 450 (Experimental conditions: resin weight $=4000 \mathrm{~g}$; bed height $=80 \mathrm{~cm}$, filtration velocity $=1.9 \mathrm{~m} / \mathrm{h}$ ) 
sand filter pretreatment (total resin weight of 4,000 $\mathrm{g}$ and flow rate of $15 \mathrm{~L} / \mathrm{h}$ (corresponding to a filtration velocity of $1.9 \mathrm{~m} / \mathrm{h})$ ). For the initial ammonium concentration of about $6 \mathrm{mg} / \mathrm{L}$ resulting from the sand filtration, the total ammonium exchange in the resin was $14,068 \mathrm{mg}$ and the amount exchanged per unit weight of resin ( $\mathrm{Q}_{\max }$ value) was $3.52 \mathrm{mg} / \mathrm{g}$ for $164 \mathrm{~h}(492 \mathrm{BV})$ of filter operation (Fig. 8).

Compared to the laboratory fluidised bed experiment, the maximum ion exchange capacity value in the household filter operation is about 2.5 times lower $(3.52 \mathrm{mg} / \mathrm{g}$ compared to $10.48 \mathrm{mg} / \mathrm{g})$. There are two main reasons for this lower value. Firstly, the presence of many other metal ions at higher concentrations in the real groundwater than in the tap water used in the laboratory competed more with ammonium for ion exchange on the resin. Secondly, the field trial set-up was suspected of having a channeling effect which could not be avoided because the inlet water entered the column near the edge of one side at the top of the column, and passed through the resin layer to the bottom before exiting the column. This led to uneven distribution of the solution within the column, so not all solutions contacted the resin for ion exchange to remove ammonium.

The household filter treated $492 \mathrm{BV}$ of water (equivalent to 2460 litres of water) before it reached the Vietnamese ammonium concentration limit of $3 \mathrm{mg} / \mathrm{L}$. Assuming that each household needs to use $15 \mathrm{~L}$ of treated water on an average per day (based on results of the pre-survey on water use demand of households in Ha Nam province), based on the results obtained, it can be estimated that each operating cycle can provide treated water (from groundwater with medium ammonium contamination of about 6 $\mathrm{mg} / \mathrm{L})$ for 164 days $(2460 / 15)$ or more than 5 months.

According to a Purolite Engineering Bulletin document (2013), Purolite C100E resin can be regenerated and reused for at least 5 years. With the initial cost for purchasing resin of $10.0 \mathrm{US} \$$ (4 $\mathrm{kg}$ (resin weight in household filter) x $2.5 \mathrm{US} \$ / \mathrm{kg}$ ) and industrial salt cost for regeneration process of 8.4 US\$ (12 cycles/5years (5 months use before 1 regeneration) x $2 \mathrm{~kg} /$ cycle x $0.35 \mathrm{US} \$ / \mathrm{kg}$ salt), the total cost of operating the household filter cartridge to treat ammonium in groundwater for 5 years is about 18.4 US\$ $(10+8.4)$. During this time, approximately $2460 \mathrm{~L}$ of contaminated groundwater which has the initial ammonium concentration of $6 \mathrm{mg} / \mathrm{L}$ can be treated before regenerating the material. It means that 
481 Vietnamese official standard of drinking water quality, and the cost for each treated cubic meter of 482 groundwater is as low as 0.62 US\$ (18.4/29.5).

483

484

\subsection{Surface analysis}
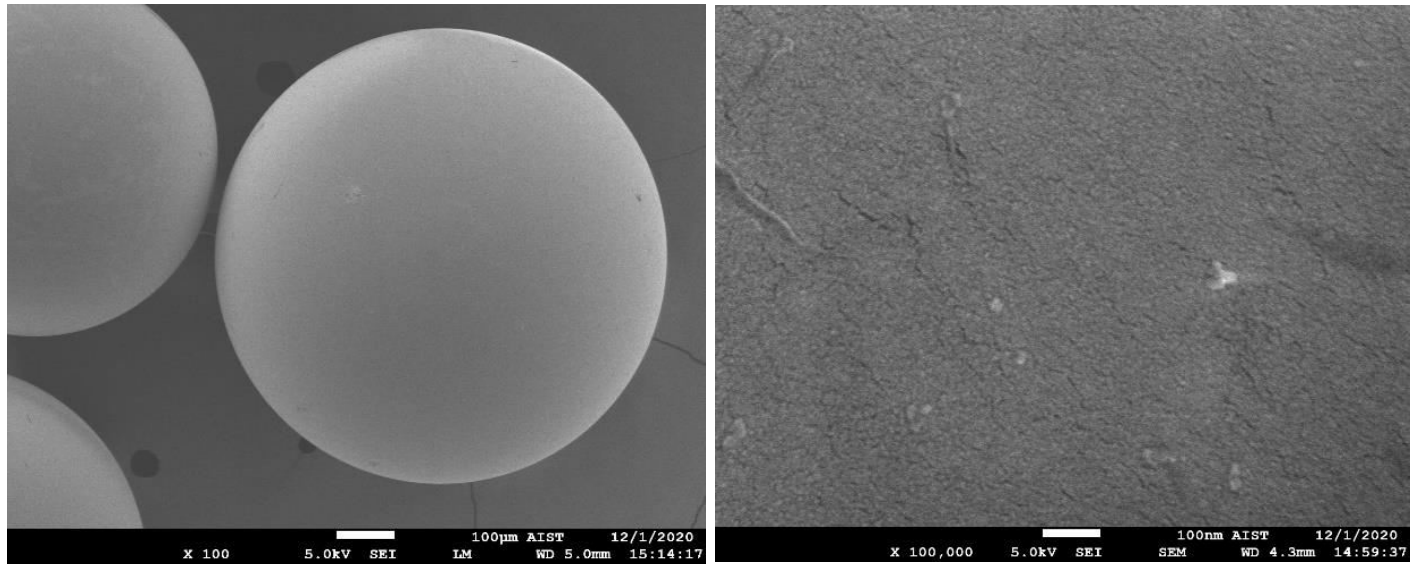

486 Fig. 9 - Unreacted Purolite C100E resin particle (Scale; left-hand side figure: x100; Right-hand side

487 figure: $\mathrm{x} 100,000)$

488
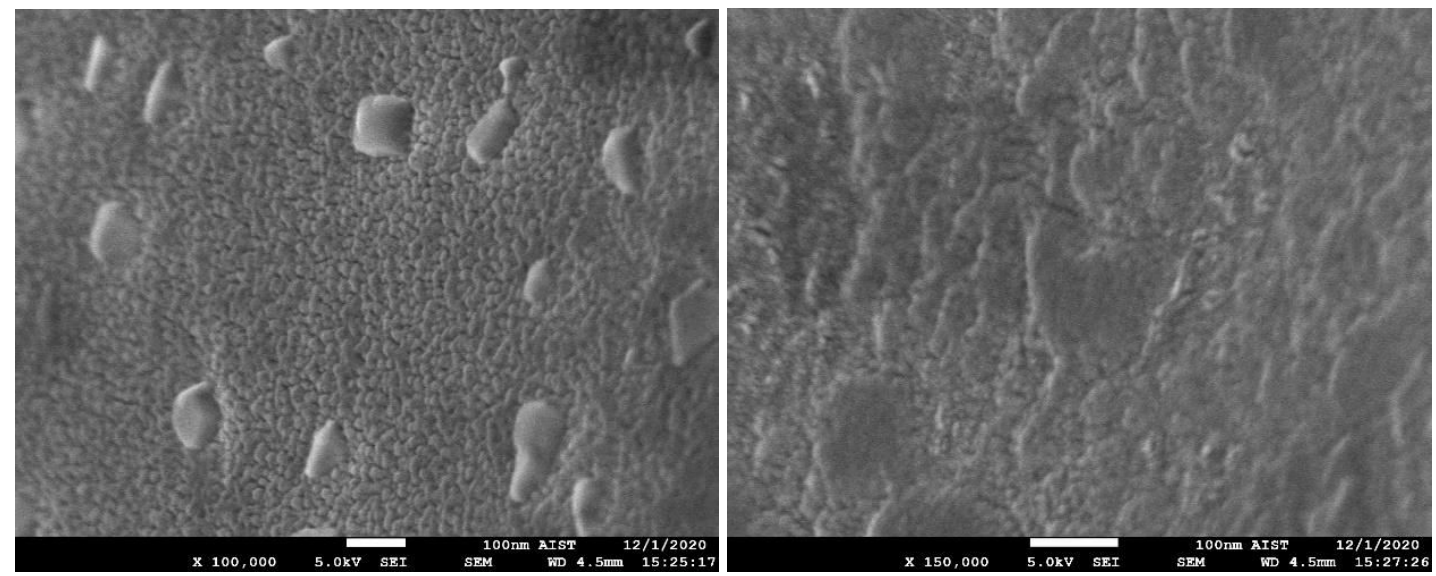

490 Fig. 10 - Reacted Purolite C100E resin particle (Scale; left-hand side figure: x100.000; Right-hand side

491 figure: $x 150,000)$ 
Table 7 - EDS analysis of the elemental composition of Purolite C100E resin before and after the 494 exchange reaction

\begin{tabular}{ccc}
\hline Element & Unreacted resin $(\mathrm{wt} \%)$ & Reacted resin $(\mathrm{wt} \%)$ \\
\hline $\mathrm{C}$ & 61.5 & 65.3 \\
$\mathrm{O}$ & 12.2 & 19.2 \\
$\mathrm{Na}$ & 7.6 & 2.8 \\
$\mathrm{~N}$ & 0.0 & 4.4 \\
\hline
\end{tabular}

495

496

497

The surfaces of Purolite C100-E particles were analysed utilising the SEM method before and after the ion exchange process. SEM images of the unreacted and reacted resin particles are shown in Fig. 9 and Fig. 10, respectively. As can be seen from these depictions, prior to the ion exchange reaction the surface of resin particles was quite smooth. After the reaction, cracks appeared on the particle surface indicating that ion exchange took place causing the cracks on the surface of resin particles to appear.

The EDS analysis was conducted to determine the elemental composition of the resin before and after the exchange reaction. Results show that $\mathrm{Na}$ concentration decreased while $\mathrm{N}$ concentration increased after the reaction, thus confirming that $\mathrm{NH}_{4}{ }^{+}$(represented by $\mathrm{N}$ in EDS analysis) has exchanged with $\mathrm{Na}^{+}$ in the resin (Table 7). Before the reaction, the sodium content in the resin was $7.6 \%$, while the nitrogen content of the material was approximately zero. After the reaction, the sodium content dropped by $4.8 \%$, meanwhile nitrogen content increased by $4.4 \%$. This is the same as a sodium content decrease of 0.21 meq/100 $\mathrm{g}$ and an ammonium content increase of $0.31 \mathrm{meq} / 100 \mathrm{~g}$. These figures do not indicate a 1:1 exchange in terms of charge balance between the two cations. The excess ammonium adsorbed on the resin may be a result of processes other than electrostatic adsorption, such as H-bonding. Sica et al. (2014) also reported that ammonium exchange with sodium on Purolite $\mathrm{C} 150 \mathrm{H}$ did not occur on a 1:1 equivalent basis. Using EDS measurement, they found that 0.39 equivalent units of sodium was replaced by 1.13 equivalent units of ammonium and explained the higher amounts of ammonium adsorption as due to its adsorption on low polar surface. Another reason for the unequal equivalents of exchange between the two 
514 cations could be because EDS - which measures the concentrations only on surface layers of a few 515 micrometers of adsorbent - is not entirely reliable in providing accurate concentrations of the adsorbed 516 ammonium and sodium (Kalaruban et al., 2016).

\section{Conclusions}

This study shows that the cation exchange resin Purolite C100E can remove ammonium from contaminated water effectively applying a wide $\mathrm{pH}$ range from 3 to 8 . Most of the ammonium exchanged

521 rapidly on the resin within a contact time of $10 \mathrm{~min}$, and the exchange process reached equilibrium at 522 around 45 min. Both Pseudo-first order and Pseudo-second order model can be applied to describe the 523 kinetics of the exchange process. Equilibrium exchange data fitted to both Langmuir and Freundlich

524 isotherm models. The Langmuir maximum exchange capacity calculated based on data from an 525 experiment using low ammonium concentrations in solution (typical of most contaminated groundwaters)

526 was $18.37 \mathrm{mg} / \mathrm{L}$. However, when high initial concentrations were used this capacity increased to 40.16 $527 \mathrm{mg} / \mathrm{L}$ which is higher than most of the values reported in literature for many synthetic and natural resins. 528 On a weight basis, magnesium ion in the solution reduced ammonium exchange the most among the co529 ions tested, followed by calcium and potassium.

530 The results from fluidised bed studies using synthetic water reveal that Purolite C100E resin has good 531 potential to treat several bed volumes of contaminated water by maintaining the effluent ammonium 532 concentration below the Vietnam drinking water standard. The breakthrough data was satisfactorily 533 described by the Thomas model. The used fluidised bed can be regenerated using $\mathrm{NaCl}$ leaching at least 534 three times and reused without losing much of the exchange capacity for ammonium, thus the operating 535 cost can be reduced significantly. In a household field trial test lasting one week, the resin could reduce 536 the ammonium concentration in groundwater after sand filtration pretreatment continuously to below the 537 Vietnam permissible concentration. A cost analysis on the use of Purolite C100E resin for the treatment of 538 a typical contaminated groundwater $(6 \mathrm{mg} / \mathrm{L}$ of ammonium $)$ demonstrated that the cost for treating each 539 cubic meter of groundwater can be as low as 0.62 US\$. 


\section{Acknowledgment}

This study was financially supported by the Aus4Innovation program - a development cooperation initiative funded by the Australian Department of Foreign Affairs and Trade and InnovationXchange. It is managed by the Commonwealth Scientific and Industrial Research Organization, in partnership with the Ministry of Science and Technology of Vietnam.

\section{References}

Aksu, Z., Gönen, F., 2004. Biosorption of phenol by immobilized activated sludge in a continuous packed bed: Prediction of breakthrough curves. Process Biochem. 39, 599-613.

Aliewi, A., Al-Khatib, I.A., 2015. Hazard and risk assessment of pollution on the groundwater resources and residents' health of Salfit District, Palestine. J. Hydrol. Reg. Stud. 4, 472-486.

Alshameri, A., Ibrahim, A., Assabri, A.M., Lei, X., Wang, H., Yan, C., 2014. The investigation into the ammonium removal performance of Yemeni natural zeolite: Modification, ion exchange mechanism, and thermodynamics. Powder Technol. 258, 20-31.

Aral, N., Günay, A., Sevimoğlu, O., Çali, M., Debik, E., 1999. Ammonia removal from aqueous solution by ion exchange using natural zeolite. Fresenius Environ. Bull. 8, 344-349.

Demir, S., Top, H., Balkose, A., Ülkü, D., 2008. Dye adsorption behavior of Luffa cylindrica fibers. J. Hazard. Mater. 153, 389-394.

Ding, Y., Sartaj, M., 2016. Optimization of ammonia removal by ion-exchange resin using response surface methodology. Int. J. Environ. Sci. Technol. 13, 985-994.

Freundlich, H.M., 1906. Over the Adsorption in Solution. J. Phy. Chem. 57, 385-470.

Halim, A.A., Latif, M.T., Ithnin, A., 2013. Ammonia removal from aqueous solution using organic acid modified activated carbon. World Appl. Sci. J. 24, 1-6.

Hedström, A., Amofah, L.R., 2008. Adsorption and desorption of ammonium by clinoptilolite adsorbent in municipal wastewater treatment systems. J. Environ. Eng. Sci. 7, 53-61. 
565 Huang, Y., Du, Y., Ma, T., Deng, Y., Tao, Y., Xu, Y., Leng, Z., 2021. Dissolved organic matter 566 characterization in high and low ammonium groundwater of Dongting Plain, central China. Ecotoxicol. 567 Environ. Saf. 208, 111779.

568 Jorgensen, T.C., Weatherley, L.R., 2003. Ammonia removal from wastewater by ion exchange in the 569 presence of organic contaminants. Water Res. 37, 1723-1728.

570 Kalaruban, M., Loganathan, P., Shim, W.G., Kandasamy, J., Naidu, G., Nguyen, T.V., Vigneswaran, S., 571 2016. Removing nitrate from water using iron-modified Dowex 21K XLT ion exchange resin: Batch 572 and fluidised-bed adsorption studies. Sep. Purif. Technol. 158, 62-70.

573 Khalil, A., Sergeevich, N., Borisova, V., 2018. Removal of ammonium from fish farms by biochar 574 obtained from rice straw: Isotherm and kinetic studies for ammonium adsorption. Adsorpt. Sci. $575 \quad$ Technol. 36, 1294-1309.

576 Kumar, K.V., Sivanesan, S., 2006. Selection of optimum sorption kinetics: Comparison of linear and non577 linear method. J. Hazard. Mater. 134, 277-279.

578 Langmuir, I., 1918. The adsorption of gases on plane surfaces of glass, mica and platinum. J. Am. Chem. $579 \quad$ Soc. $40,1361-1403$.

580 Li, K., Zheng, Z., Huang, X., Zhao, G., Feng, J., Zhang, J., 2009. Equilibrium, kinetic and thermodynamic 581 studies on the adsorption of 2-nitroaniline onto activated carbon prepared from cotton stalk fibre. J. 582 Hazard. Mater. 166, 213-220.

583 Nguyen, T.T.Q., Loganathan, P., Nguyen, T.V., Vigneswaran, S., Ngo, H.H., 2020. Iron and zirconium 584 modified luffa fibre as an effective bioadsorbent to remove arsenic from drinking water. Chemosphere. $585 \quad 258,127370$.

586 Nguyen, V.A., Bang, S., Viet, P.H., Kim, K.W., 2009. Contamination of groundwater and risk assessment 587 for arsenic exposure in Ha Nam province. Vietnam, Environ. Int. 35, 466-472.

588 Nitzsche, K.S., Lan, V.M., Trang, P.T.K., Viet, P.H., Berg, M., Voegelin, A., Friedrich, B.P., Zahoransky, 589 J., Muller, S.K., Byrne, J.M., Schroder, C., Behrens, S., Kappler, A., 2015. Arsenic removal from 
drinking water by a household sand filter in Vietnam - Effect of filter usage practices on arsenic

591 removal efficiency and microbiological water quality. Sci. Total Environ. 502, 526-536.

592 Nur, T., Johir, M.A.H., Loganathan, P., Nguyen, T., Vigneswaran, S., Kandasamy, J., 2014. Phosphate 593 removal from water using an iron oxide impregnated strong base anion exchange resin. J. Ind. Eng. 594 Chem. 20, 1301-1307.

595 Purolite Co., 2013. Purolite Engineering Bulletin. (accessed in August 2021) 596 https://www.purolite.com/dam/jcr:c3ab3898-f067-474c-9e45-03c53324ec6d/C100 Sodium Cycle.pdf.

597 Rusmin, R., Sarkar, B., Liu, Y., Mcclure, S., Naidu, R., 2015. Applied Surface Science Structural 598 evolution of chitosan - palygorskite composites and removal of aqueous lead by composite beads. $599 \quad$ Appl. Surf. Sci. 353, 363-375.

600 Sabogal-Paz, L.P., Campos, L.C., Bogush, A., Canales, M., 2020. Household slow sand filters in 601 intermittent and continuous flows to treat water containing low mineral ion concentrations and 602 Bisphenol A. Sci. Total Environ. 702, 135078.

603 Shaw, G.D., White, E.S., Gammons, C.H., 2013. Characterizing groundwater-lake interactions and its 604 impact on lake water quality. J. Hydrol. 492, 69-78.

605 Sica, M., Duta, A., Teodosiu, C., Draghici, C., 2014. Thermodynamic and kinetic study on ammonium 606 removal from a synthetic water solution using ion exchange resin. Clean Technol. Environ. Policy. 16, $607 \quad 351-359$.

608 Tanabe, K., Yokota, H., Hironaka, H., Tsushima, S., Kubota, Y., 2001. Arsenic pollution of groundwater 609 in Bangladesh. Appl. Organomet. Chem. 15, 241-251.

610 Tchobanoglous, G., Stensel, H.D., Tsuchihashi, R., Burton, F., 2014. Metcalf and Eddy | AECOM611 Wastewater Engineering Treatment and Resource Recovery, fifth ed. McGraw-Hill, New York.

612 Terin, U.C., Sabogal-Paz, L.P., 2019. Microcystis aeruginosa and microcystin-LR removal by household 613 slow sand filters operating in continuous and intermittent flows. Water Res. 150, 29-39.

614 Thomas, H.C., 1944. Heterogeneous ion exchange in a flowing system. J. Am. Chem. Soc. 66, 16646151666. 
616 Tseng, J.Y., Chang, C.Y., Chang, C.F., Chen, Y.H., Chang, C.C., Ji, D.R., Chiu, C.Y., Chiang, P. C.,

617 2009. Kinetics and equilibrium of desorption removal of copper from magnetic polymer adsorbent. J.

618 Hazard. Mater. 171. 370-377.

619 Vietnam Environment Agency, 2016. Vietnam's National Environment Report 2011 - 2015. Hanoi, 620 Vietnam.

621 Vietnamese Department of Preventive Medicine \& Environment, 2009. QCVN 01:2009/BYT: National 622 technical regulation on drinking water quality. Hanoi, Vietnam.

623 Volkov, A.G., Paula, S., Deamer, D.W., 1997. Two mechanisms of permeation of small neutral molecules 624 and hydrated ions across phospholipid bilayers. Bioelectrochem. Bioenerg. 42, 153-160.

625 Vu, T.M., Trinh, V.T., Doan, D.P., Van, H.T., Nguyen, T.V., Vigneswaran, S., Ngo, H.H., 2017. 626 Removing ammonium from water using modified corncob-biochar. Sci. Total Environ. 579, 612-619.

627 Wang, Y.F., Lin, F., Pang, W.Q., 2007. Ammonium exchange in aqueous solution using Chinese natural 628 clinoptilolite and modified zeolite. J. Hazard. Mater. 142, 160-164.

629 Wassie, A.B., Srivastava, V.C., 2016. Teff straw characterization and utilization for chromium removal 630 from wastewater: Kinetics, isotherm and thermodynamic modelling. J. Environ. Chem. Eng. 4, 1117$631 \quad 1125$. 


\section{Declarations}

633

634

635

636

637

638

639

640

641

642

643

644

645

646

647

648

649

650

651

652

653

654

655

656

657

658

659

660

\section{Ethics approval and consent to participate:}

Not applicable

\section{Consent for publication:}

Not applicable

\section{Availability of data and materials:}

The datasets used and analysed during the current study are available from the corresponding author on reasonable request.

\section{Competing interests:}

The authors declare that they have no competing interests

\section{Funding:}

This study was financially supported by the Aus4Innovation program - a development cooperation initiative funded by the Australian Department of Foreign Affairs and Trade and InnovationXchange.

\section{Authors' contributions:}

i. Conceptualization: Tien Vinh Nguyen

ii. Methodology: Paripurnanda Loganathan, Le Minh Tran, Tien Vinh Nguyen

iii. Formal analysis and investigation: Dai Quyet Truong

iv. Writing - original draft preparation: Dai Quyet Truong

v. Writing - review and editing: Paripurnanda Loganathan, Le Minh Tran, Duc Loi Vu, Tien Vinh Nguyen, Saravanamuthu Vigneswaran, Gayathri Naidu

vi. Funding acquisition: Tien Vinh Nguyen, Saravanamuthu Vigneswaran

vii. Resources: Le Minh Tran, Duc Loi Vu, Tien Vinh Nguyen, Saravanamuthu Vigneswaran viii. Supervision: Le Minh Tran, Tien Vinh Nguyen

\section{Acknowledgements:}

This study was financially supported by the Aus4Innovation program - a development cooperation initiative funded by the Australian Department of Foreign Affairs and Trade and InnovationXchange. It is managed by the Commonwealth Scientific and Industrial Research Organization, in partnership with the Ministry of Science and Technology of Vietnam. 